\title{
The Myth of the Economic Strength of the United States
}

\author{
Eduardo Alfonso Rosales Herrera \\ National Autonomous University of Mexico, Mexico City, Mexico
}

\begin{abstract}
The US government constantly repeats that the country's economy has solid foundations and that it is growing, even the current president announces that his country's economy is the strongest in history, but the truth is that there are macroeconomic indicators that contradict it. The United States is experiencing a structural crisis of long evolution that is reflected in colossal indebtedness, in the concentration of wealth, the increase in poverty, and in the trade and budget deficits. During the second administration of President Obama, the ratio of debt to Gross Domestic Product (GDP) reached $100 \%$ and since then, the amount of debt has continued to increase. With the arrival of Donald Trump, the US economy registers historical deficits and the debt figure has already exceeded 21 trillion dollars, which augurs in the medium term a decline in GDP growth and a potential recession, but in the long term and not reversing this trend could present a financial catastrophe. This situation will negatively impact other indicators which could generate a climate of uncertainty, nervousness, and instability that will make the crises of 1929 and 2008-2009 pale.
\end{abstract}

Keywords: Structural crisis, public indebtedness, concentration of wealth, increase in poverty, trade and budget deficits

\section{Public Debt}

First of all, it should be said that every State prepares a general budget year after year that is an estimate of the income and expenditures that it will have and, based on these data, what is known as public expenditure. Of course to make this forecast has to take into account various parameters such as inflation, unemployment, and the growth or decrease of the Gross Domestic Product (GDP) and others.

Of course, it is very difficult for governments to calculate exactly the money they will receive and the monetary resources that they will spend because there are innumerable factors that alter this estimate.

If the State receives more and spends less than the government accounts register surpluses, but if the opposite happens, it incurs a deficit. In this second case, governments resort to both external and internal loans, which is what is called public debt. In order to obtain monetary resources, governments issue instruments such as treasury bond, which in terms of international finance is known as sovereign debt.

In periods of low collection and especially in times of economic crisis, internal and external financial assistance is necessary; however there are many countries in the world that have long used debt as a mechanism to cover their expenses and have entered into a vicious circle from which they have not been able to leave. Such is the case of the United States, which has incurred a deficit since the monitoring of its public expenditure.

Eduardo Alfonso Rosales Herrera, Ph.D. in International Relations, full-time definitive professor at the Postgraduate School of Higher Studies Acatlán, National Autonomous University of Mexico, Mexico City, Mexico. 


\section{Second Half of the 20th Century}

In the following figure we can observe the indebtedness observed in the United States in the period 1940-2012, that is, from the beginning of the Second World War until the end of the first administration of President Barack Obama.

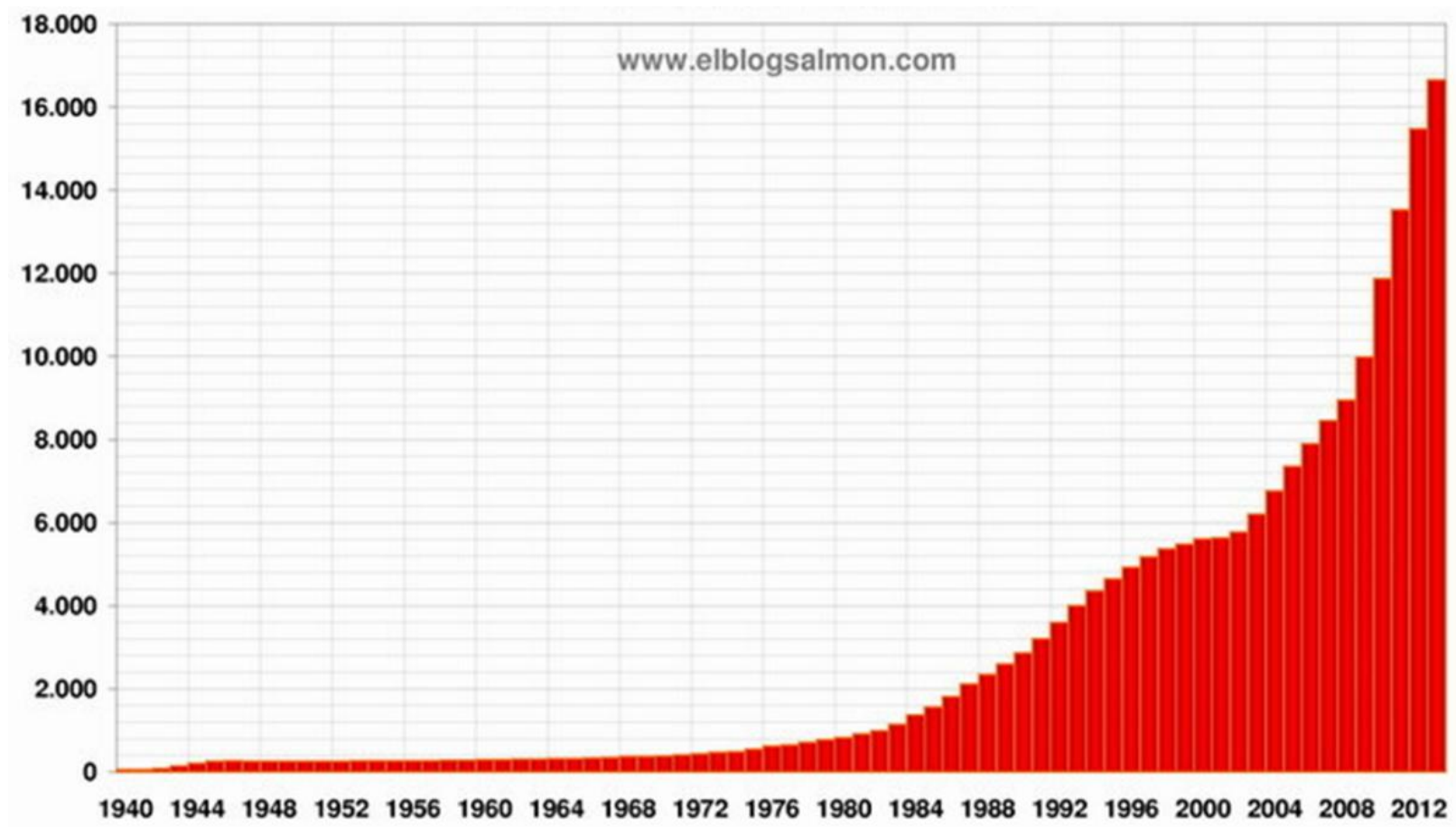

Figure 1. United States public debt 1940-2013 (in billions of dollars). Moreno (2013).

As you can see the debt remained stable and under control for 40 years, from 1940 to 1980. It is important to point out that in these four decades the cold war was lived, which represented a very important expense for the United States due to the arms race and the space race he waged against the Soviet Union (USSR) but also there were other huge expenditures caused by the Vietnam War, one of the longest armed conflicts in its history, as well as other problems such as the impact of the oil embargo that substantially increased the price of hydrocarbons; however, the high agricultural and industrial productivity, the constant innovation, the growing exports, the economic weakness of Europe and Japan due to the aftermath of the war and the inexistence of an economic pole that generated a rivalry and competition such as current China allowed it to achieve half of world GDP and consequently take the Western capitalism's leadership.

\section{The Last Two Decades of the 20th Century}

The rising curve of indebtedness began with the arrival of Ronald Reagan to the presidency when the public debt first reached the trillion dollars (Die Presse, 2006) which coincided with the implementation of its economic policy called "reganomics" inspired by the neoliberal model proposed by Milton Friedman and the School of the Chicago Boys, which meant financial deregulation, a significant decrease in taxes, an increase in the deficit that went from 2.7\% to 6\% of the GDP (Budget of the United States Government, 2006) support for anti-communist movements throughout the world, military actions in Libya and Granada, among others, the 
increase in military spending that rose by almost a third, the strategic defense initiative, better known as "Star Wars" which meant an expenditure of around 25 dollar billions (Sputnik, 2019). All of the above caused the increase in the budget deficit and the consequent increase in public debt.

The assertion that the Ronald Reagan government was unbalanced finances and began the rapid rise of debt is shared by Joseph E. Stiglitz in the preface to his book Freefall America, Free Markets, and Sinking of the World.

\section{First Decade of the 21st Century}

During the government of George W. Bush, two major military operations were carried out, the first in Afghanistan to dismantle the Taliban Movement, liquidate the Al-Qaeda group, and eliminate Osama Bin Laden and the second in Iraq with two objectives, the first to overthrow the regime of Saddam Hussein and the second to locate and destroy weapons of mass destruction, something that certainly never happened because such weapons were never found.

Notwithstanding the above, the costs of both operations were very high because of the war in Afghanistan, according to very conservative estimates by Anthony Cordesman, a consultant in the State and Defense departments during the wars in Afghanistan and Iraq and strategist Arleigh A. Burke of the Center for International and Strategic Studies (CNNMoney, 2017); they were 841 billion and those of Iraq, according to Joseph E. Stiglitz and Linda J. Bilmes, rose to three trillion dollars (Stiglitz \& Bilmes, 2008, p. 12).

Other studies, such as those of Neta Crawford, co-director of the Cost of Wars Project at Brown University (CNNMoney, 2017), consider that the total spending of wars in Iraq, Afghanistan, and Pakistan since 2001 reaches five trillion dollars.

Regardless of the figures indicated, the truth is that the costs of both wars, those of Afghanistan and Iraq, were enormous.

In 2007, the crisis of subprime mortgages also appeared, which caused a crisis in the financial system of the United States and later in the world, which caused the bankruptcy of several banks, starting with Lehman Brothers. This evidently sharpened the economic problems of the United States for the monumental cost represented by the bank rescue and several companies such as the automotive industry.

Derived also from the economic crisis caused by the housing bubble, the Federal Reserve carried out exceptional measures such as the quantitative easing that injected a total of 4.5 trillion dollars into the US economic circuit, which obviously also had an impact on that country's public debt.

On the other hand, the following figure allows us to observe the indebtedness of the United States in the period 2001-2011, that is to say a decade in which this country faced the worst attacks in its history (S-11) and the consequent crusade against terrorism started by George W. Bush and continued by Barack Obama. 


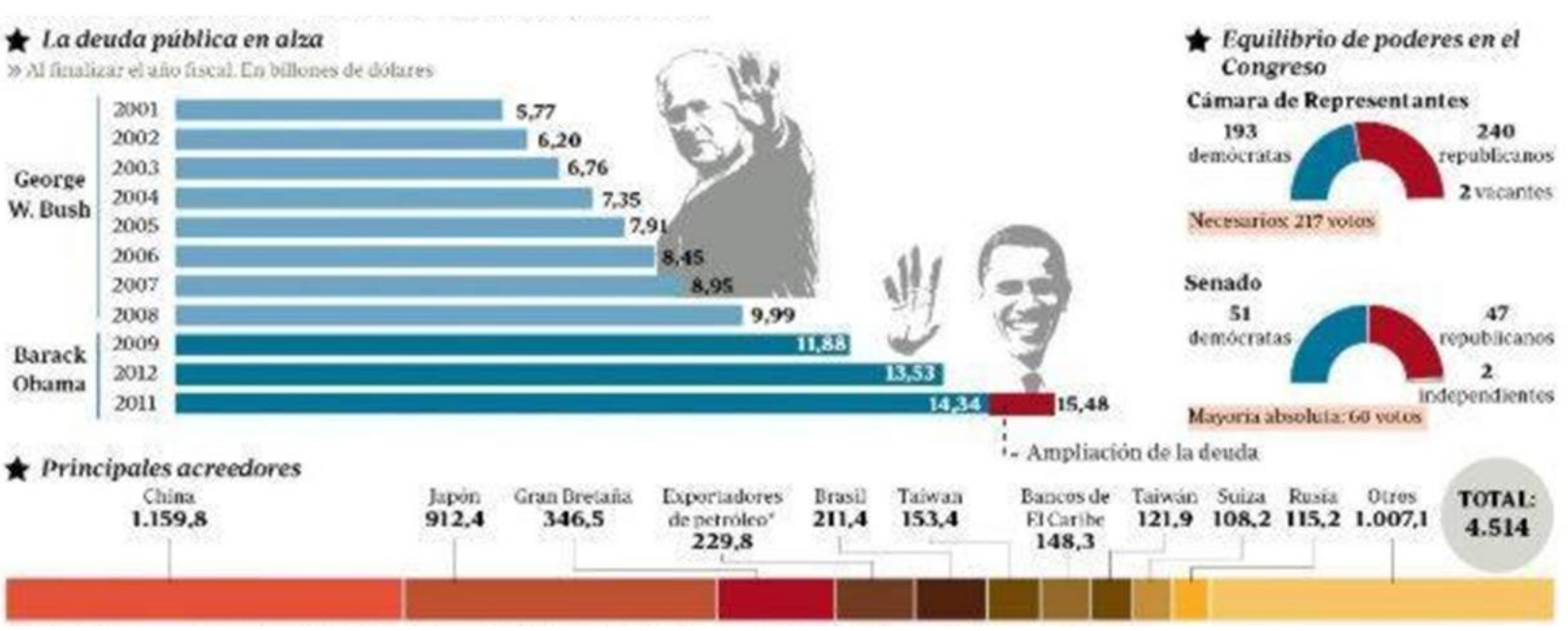

Figure 2. The historical tradition of indebtedness. ABC.es Internacional (w/d).

\section{Second Decade of the 21st Century}

On the other hand, it is important to point out that for the year of 2011 China consolidated itself as the first lender in the United States, which definitively broke with the idea that the first economic power in the world should be the creditor country, not the debtor; besides Japan and the United Kingdom already appear as the second and third lenders.

According to the previous figure, the fact that China has allocated more than 1.15 trillion dollars to loans to the United States evidently reflects that the Asian giant had monetary surpluses in those years coming from the double-digit growth of its Gross Domestic Product, the trade surplus which recorded its trade balance and the consequent accumulation of foreign exchange reserves.

Other studies tell us that the debt of the United States with China is 1.8 trillion dollars and that for the payment of interest the Chinese government receives almost 50 billion dollars a year (Ferrero, 2015) which reveals the financial power of Beijing.

So far this century, the economic strength of countries like China contrasts with the weakening of the United States, especially after the events of S-11. The waning period of the economy has been so long that it makes us think that this country has gone from a conjunctural crisis to a structural one and that the last governments have not been able to stop and less reverse. About the Asian giant it is necessary to emphasize that it is the first commercial power in the world, the largest consumer of energy on the planet, the first producer of steel, coal, and cement, the largest shipbuilder; it also has the largest merchant marine and the largest number of troops military and is, in addition, the great world lender.

Returning to the United States, the administration of President Barack Obama was not different from the previous ones because when he assumed the presidency the debt was 10.6 trillion dollars, but when his government ended he reached 19.5 trillion, which means that in eight years the debt doubled. Obama faced the challenge of taking his country out of the worst crisis in history after that of 1929; however, this achievement had a colossal impact on the issue of indebtedness.

In the 21st century there have been three different administrations, first that of the Republican George W. Bush, the second that of the Democrat Barack Obama, and the third that of Donald Trump but the final results of the indebtedness have been disappointing. 
To illustrate the seriousness of the problem, let's see the following table.

Table 1

Historical Debt of the United States

\begin{tabular}{lll}
\hline Year & Amount of debt & Accumulation period \\
\hline 1981 & 1 trillion dollars & 200 years \\
2008 & 10 trillion dollars & 27 years \\
2016 & 18 trillion dollars & 8 years \\
2018 & 21 trillion dollars & 2 years \\
2019 & 22 trillion dollars & 1 year \\
\hline
\end{tabular}

Source: OroyFinanzas.com (2016). Statistical chart of own elaboration.

The data show that the rate of accumulation of the public debt of the United States is vertiginous, practically one trillion per year and very difficult to stop. The administration of President Trump has taken measures similar to those of former President Reagan to boost GDP growth, such as lowering taxes, increasing infrastructure spending, and expanding military spending. However, all of the above have weakened revenues and expanded the debt.

A first consideration is that the US government cannot function without the monetary resources coming from loans, in other words, the US economy is not healthy or sustainable because it is unable to generate surpluses that reverse the trend of indebtedness regardless of who the president is and the party to which it belongs.

Currently the United States ranks sixth worldwide among the most indebted countries in the world taking into consideration the debt/Gross Domestic Product ratio, but in the next decade it is absolutely foreseeable that it will reach the third place which could cause a global financial catastrophe.

\section{Debt per Capita}

Another problem that derives from this situation is the increase in per capita debt. Graphs on this issue are just as alarming as those on public debt.

In February 2012, The Weekly Standard published the following figure prepared by the office of Senator Jeef Sesions. 


\section{America's Per Capita Government Debt Worse Than Greece}

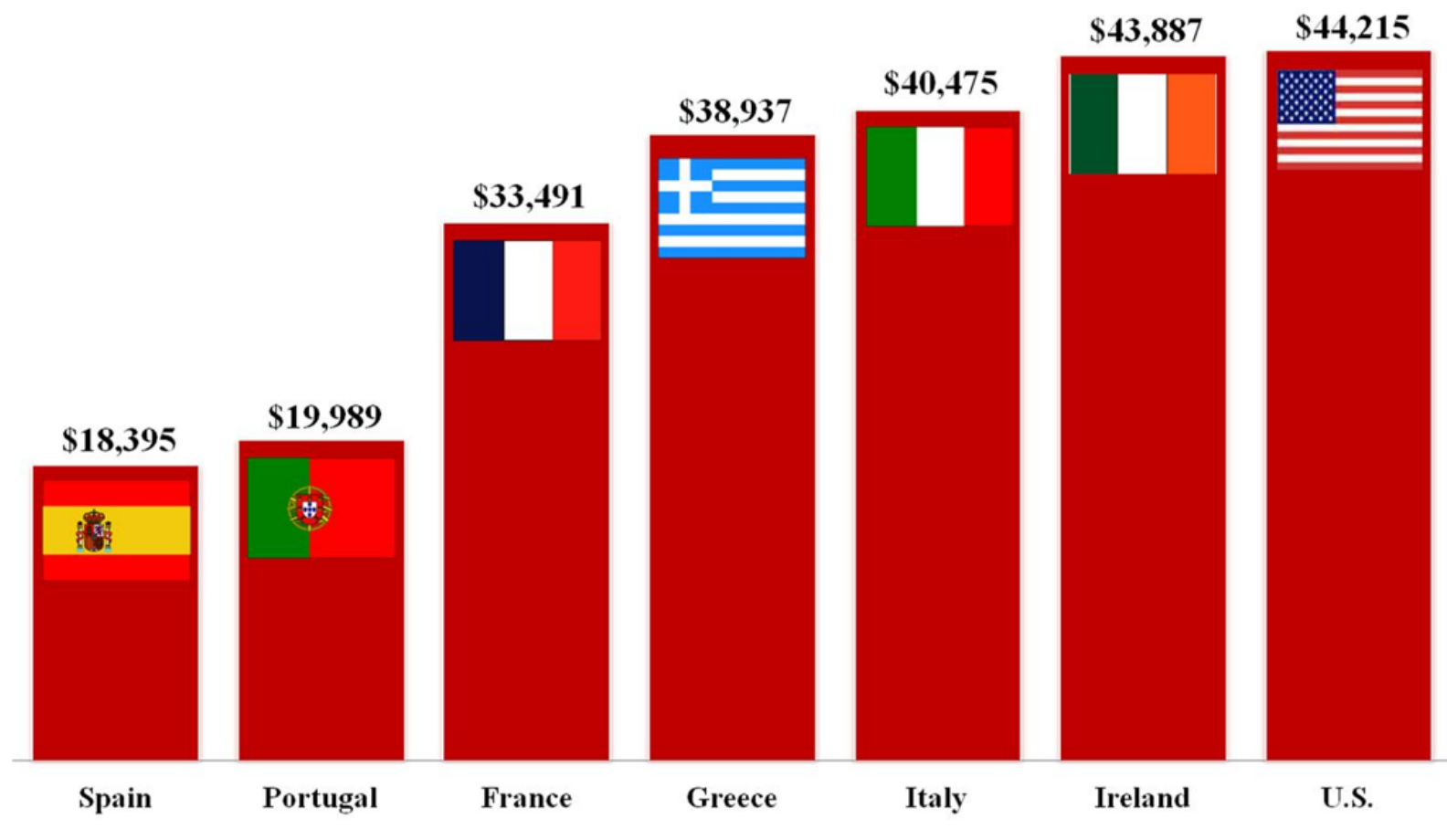

Figure 3. America's per capita government debt worse than Greece. Freedman (2012).

In this same source it is mentioned that the United States has the highest debt per person than any of the member countries of the European Union, including countries that at the beginning of the second decade of the 21 st century were disparagingly called "PIGS": Portugal, Ireland, Greece, and Spain, because all of them were in a severe economic crisis that to date they have not managed to overcome in its entirety. The alarming thing about this matter is that six years later, in 2019, this item continues to grow proportionally with the US public debt, which means that every child born in this country today owes approximately $\$ 61,900$ (Sputniknews, 2018) that is 17,685 thousand dollars more than in 2013. This is a very high amount and therefore very worrying.

It is important to note that the previous figure "America's per Capita Government Debt Worse Than Greece" was drawn up in January 2013, just when the amount of the United States debt exceeded 100\% of the Gross Domestic Product. The following table exemplifies the above.

Table 2

Comparative Gross Domestic Product/Total Debt

\begin{tabular}{lll}
\hline Year & Gross Domestic Product & Total debt \\
\hline 2013 & $\$ 15,294,300,000,000$ & $\$ 15,419,800,222,325$ \\
\hline
\end{tabular}

Source: Conn (2013). Statistical chart of own elaboration.

In order to have an additional comparative figure that shows us the problem of the per capita debt of the American society, we mention that Mexico, a country considered to be emerging and with an economy 20 times smaller than that of the United States, has a debt/Gross Domestic Product ratio of around of $45 \%$ while the United States has it at approximately $120 \%$. The above means that the per capita debt of Mexicans is, at an 
exchange rate of $\$ 19.00$ pesos per dollar, of $\$ 4,475$ dollars, while each American owes more than $\$ 60,000$ dollars, that is, 13 times greater and continues to rise.

Table 3

Percentage Evolution of the Ratio of Public Debt to Debt per Capita

\begin{tabular}{lll}
\hline Year & Public debt (\% GDP) & Debt per capita \\
\hline 1981 & $40.33 \%$ & $\$ 5,041$ \\
2008 & $73.79 \%$ & $\$ 24,250$ \\
2016 & $107.17 \%$ & $\$ 55,810$ \\
2018 & $120 \%$ (aprox) & $\$ 63,065$ (aprox) \\
\hline
\end{tabular}

Source: Expansión/Datosmacro.com (2018). Statistical chart of own elaboration.

All of the above leads us to think that the US economy is addicted to indebtedness and regardless of the official discourse this parameter is perhaps the most evident symptom of the incurable, progressive, and deadly disease that it suffers and that no democratic or republican government has been able to resolve. Currently the debt is unpayable and this explains why the Standard \& Poors Company reduced the US debt rating in the year of 2011 by one step, a fact unprecedented in the history of that country.

There is another negative fact that adds to the above and is that any debt generates interest payments. The data published by the New York Times states that Washington will pay in 2019 almost 400 billion dollars for debt service, but to continue this uncontrolled process of indebtedness, the interest to be paid within 10 years will rise to 900 billion of dollars (Meschoulam, 2018).

Table 4

Interest Generated by US Debt

\begin{tabular}{ll}
\hline Year & Payment of interest in billions of dollars \\
\hline 2017 & 260 \\
2019 & 390 \\
2029 & 900 (estimate) \\
\hline
\end{tabular}

Source: Statistical chart of own elaboration.

In a short time, the expenditures for this concept will be more than those of any other item of the public budget.

At this moment it is pertinent to point out that one of the items of public spending that represent a real drain on the US Treasury is the military budget. In 2018 it stood at 649 billion which represents more than a third of the world's spending and "is greater than the total of the expenses of the other eight countries that allocate more resources to this same item", according to data published by the International Institute of Studies for the Peace of Stockholm (IISPS) (EC/AFP, 2019). To give an example of the costly and perhaps unnecessary military expenditures, we note that in 2017 Trump presided over the inauguration ceremony of the 11th aircraft carrier of the US navy, Gerald R. Ford, which cost 13 billion dollars, also on that occasion he promised to start the construction of another one that could cost 15 billion dollars. Of course, these expenses do not include the maintenance or operation of aircraft carriers, but in addition these types of warships may be vulnerable targets when we know the existence and development of 21 st century weapons such as hypersonic missiles with multiaxial maneuverability, high submarine drones speed equipped with nuclear weapons, fifth-generation fighter aircraft, and high precision laser cannons to name a few examples. 
The problem of the current administration is that it is opening many battle fronts around the world from the economic-commercial as with China to the military with Iran and all this generates huge costs.

In this context and in the frame of the verbal confrontation between the US president and Iranian President Hassan Rouhani, at Washington's insistence that the Tehran regime renounces its alleged nuclear weapons program, Trump said that the United States "is by far the most powerful military force in the world, with 1.5 trillion dollars invested during the last two years" (Agencies, 2019) (referring to the military budget). It is more than exemplary data provided by the tenant of the White House.

In addition, the combination of lower revenues, higher military spending, and a larger infrastructure budget of up to two trillion will at some point impact not only fiscal revenues but also the Gross Domestic Product, which could cause not only a slowdown but a recession. The United States suffers from a compulsion for debt, which implies that at some point its structural power will be diminished and, of course, its ability to influence the world.

Do not forget that apart from the public debt there is also a domestic debt that includes social benefits such as Medicare and Medicaid, the care and pensions of retired citizens, and other items. Many other debts are also worrying too much, such as that of companies that amounts to nine trillion, that of consumers that reaches 13.5 trillion, and that of students that reaches 1.5 trillion. If we add only the last three debts referred to plus the public, the figure exceeds 45 trillion dollars so the problem is monumental to the extent that in the not too distant future, there could be a scenario of financial bankruptcy for the United States government and its citizens which would cause an expansive wave that in minutes would affect the entire planet.

\section{Concentration of Wealth}

Now, with regard to the concentration of wealth, the data are alarming when we know that the richest $1 \%$ of families control almost $40 \%$ of the country's wealth (Egan, 2019) which figure that the Federal Reserve published in September of the year 2017 (Federal Reserve, 2019).

Another data related to the above indicate that $90 \%$ of families with less income now only have $23 \%$ of wealth, 33\% less than the figure in 1989, year in which the Federal Reserve began monitoring of this parameter.

Regarding income, the data are even more discouraging because in 2016, the richest $1 \%$ of families obtained $25 \%$ but $90 \%$ of the poorest ones won only $49.7 \%$, that is, less than half. This last data in particular is very alarming because in 1989, the year in which the FED began the measurement of this indicator, the income of the poorest families was $60 \%$, which means that in little more than a quarter of a century the poor are poorer because they lost more than 10\% of total income (Egan, 2017).

The previous figures are terrible and explain several things to each other, the steady increase in the fortunes of the richest men published every year by Forbes magazine, but in contrast the emergence of movements like the "Occupy Wall Street" and the rise of politicians like Bernie Sanders and Elizabeth Warren who severely criticize the concentration of wealth and the spread of poverty. Whether or not one of the two gets the democratic nomination for the 2020 elections, both are the visible face of the discontent of millions of Americans who still do not understand why it continues to decrease their income, their purchasing power, their savings, and their standard of living.

To exemplify the above, we can use the metric developed by the Italian statistician and demographer Conrado Gini, which is colloquially known as Index or Gini Coefficient and which aims to measure the 
inequality of income in a country, but also reflects adequately the gap between rich and poor or what is the same is the inequality of the distribution of wealth.

Before showing the map and the figure, it is necessary to point out that the limits of this coefficient oscillate between zero and one in which the zero would mean that there is an equitable distribution of wealth; it would be a perfectly egalitarian society in which all its members perceive the same income while the one would be the opposite, that is, a perfectly unequal society in which a single person would have all the income.

According to the United Nations (UN), when the Gini coefficient exceeds 0.40, it means that there is a considerable gap between rich and poor, which makes a potentially risky scenario due to that the differences in income of the different social classes cause an environment of polarization that would cause popular discontent or insurrection.

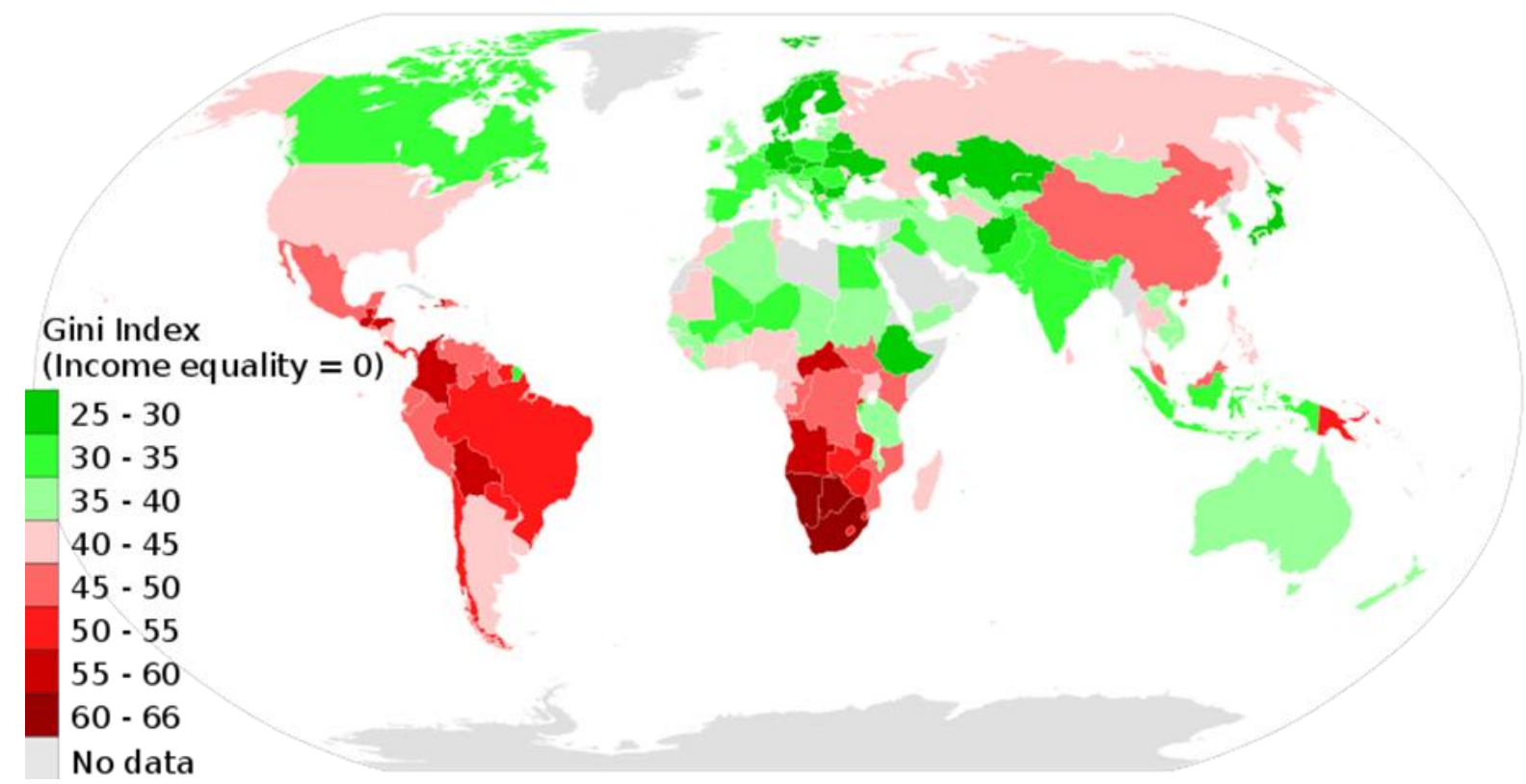

Figure 4. Gini index world map. Wikimedia.commons.org (2017).

The previous map has several readings, such as the fact that the United States already exceeds 0.40 of inequality, which places it on the threshold of a possible scenario of social upheaval. It also puts it on an equal footing with countries such as Argentina in the Americas, or Morocco in Africa, or like Thailand in South Asia and very far from other nations such as France, and even more distant from societies such as those Nordic countries.

It should be added that derived from the crisis of 2008-2009, and as a point of comparison, the United States came to have in 2011 a Gini index of 0.469 very similar to that of Mexico at that time that had a 0.472 which placed both in the 123th place of inequality among all the countries of the world. Now that according to Donald Trump, the United States has the strongest economy in its history (Yahoo Finanzas, 2018). Because his country has full employment, a substantial increase in exports, high indexes in its stock exchanges, and a high GDP per capita, the United States cannot leave the risk zone as expressed by the United Nations Organization. Thus, the official discourse is very optimistic and at the same time biased because it is based only on positive indicators without taking into account the negative ones. In the near future there are also other reasons for alarm, such as the potential decrease in the income of broad layers of society due to the technification of 
production, the distribution and marketing of goods and services, and the consequent displacement of the hand of work in addition to the unemployment of workers whose role in the productive apparatus will be affected by globalization and by activities related to the knowledge economy.

Part of this problem has been widely exposed in the book Capital in the 21st Century published by Thomas Piketty who, in summary, states that the market economy generates imbalances and asymmetries and that the best indicator to measure the impoverishment of a society is precisely that of inequality. In this sense, the system itself accumulates wealth on one side and poverty on the other. This explains the growing gap between rich and poor, not only in the United States but throughout the world.

A fact that can be useful to demonstrate the previous hypothesis is when we know that, according to Mauro Guillén, Professor of International Management at Wharton School and director of the Lauder Institute of the University of Pennsylvania, $1 \%$ of the world population concentrates $50 \%$ of planetary wealth. In the United States, an example of the above can be seen in the fact that 540 families have assets of more than one billion dollars, but the middle class remains stagnant and the poor continue to increase (Guillén cited in Montenegro, 2019). This also explains the acceptance of the leftist discourse between young people and the lower classes such as Bernie Sanders and Elizabeth Warren and Donald Trump's right-wing populist discourse between Anglo-Saxon and Protestant whites who are less affected by the globalization phenomenon.

The foregoing also explains why in several countries there is talk of economic growth, but not development. On the other hand, the increasing financialization of the economy has caused the richest to increase the holding of shares of publicly traded companies, something that the poor and marginalized cannot do, because if they do not have the money to cover their basic needs, the less acquire shares. In the United States, " $1 \%$ owns half of the country's shares, bonds and mutual funds; $50 \%$ of Americans in the lower part barely own $0.5 \%$ of these investments" (Jiménez, 2013).

\section{Poverty}

As regards this item, the American union is not in a better situation. We say the above because at the beginning of 2018 there were around 41 million poor people, that is $13 \%$ of the total population, a very high figure for the first economic power in the world.

In this country the poverty threshold is considered when a family of four has a gross income of less than 24,300 dollars per year, that is, 6,075 dollars per person.

The problem is compounded when we know that there are many counties in the United States that have up to twice the poverty level and that African American and Hispanic families are the ones that suffer most from this condition. In the case of African-Americans, the poverty rate is $22 \%$, double the average for white families (Shambaugh, 2017). 


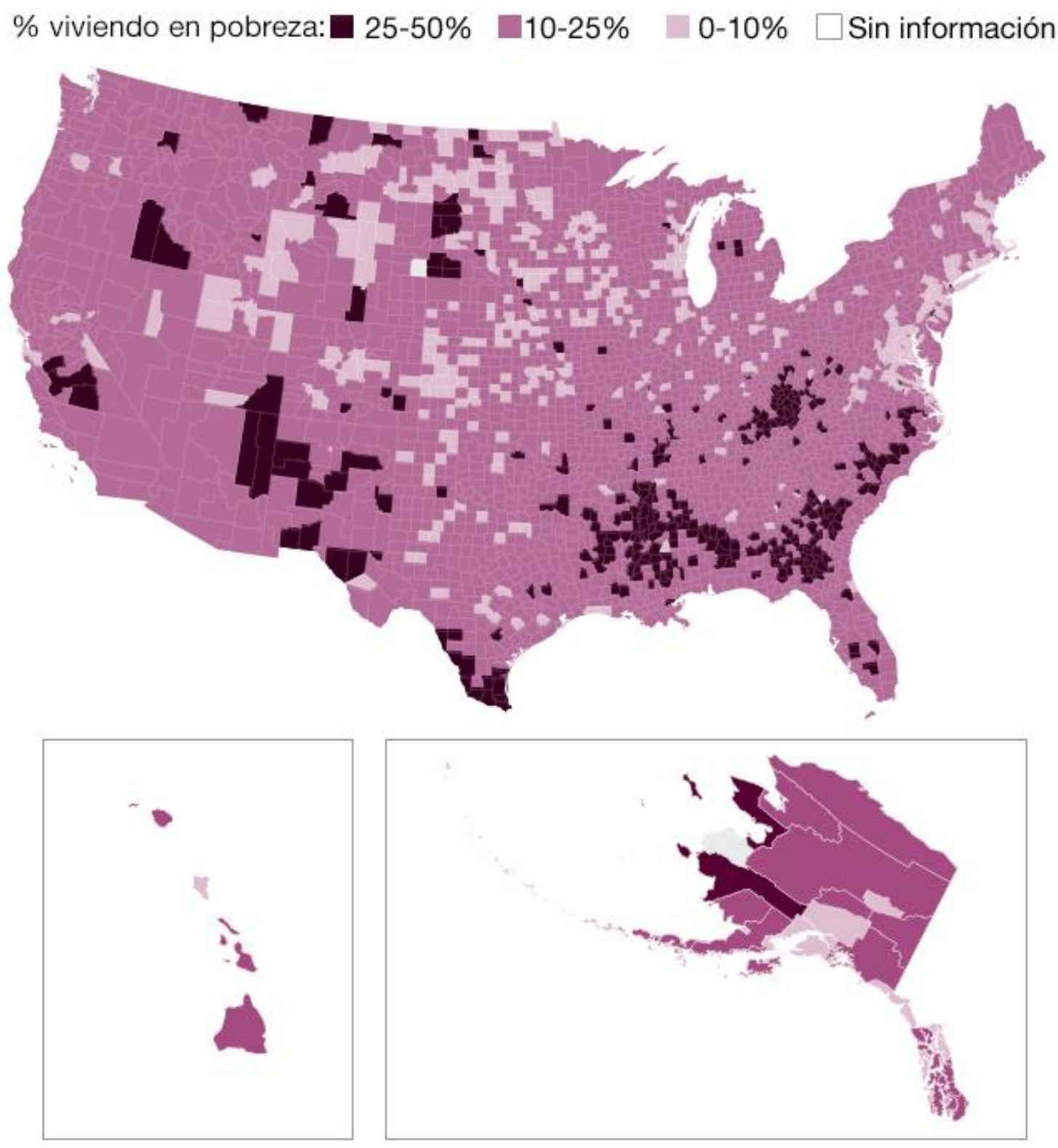

Figure 5. Where are the poor in the United States? Which counties have the highest and lowest poverty rates? Shambaugh (2017). 


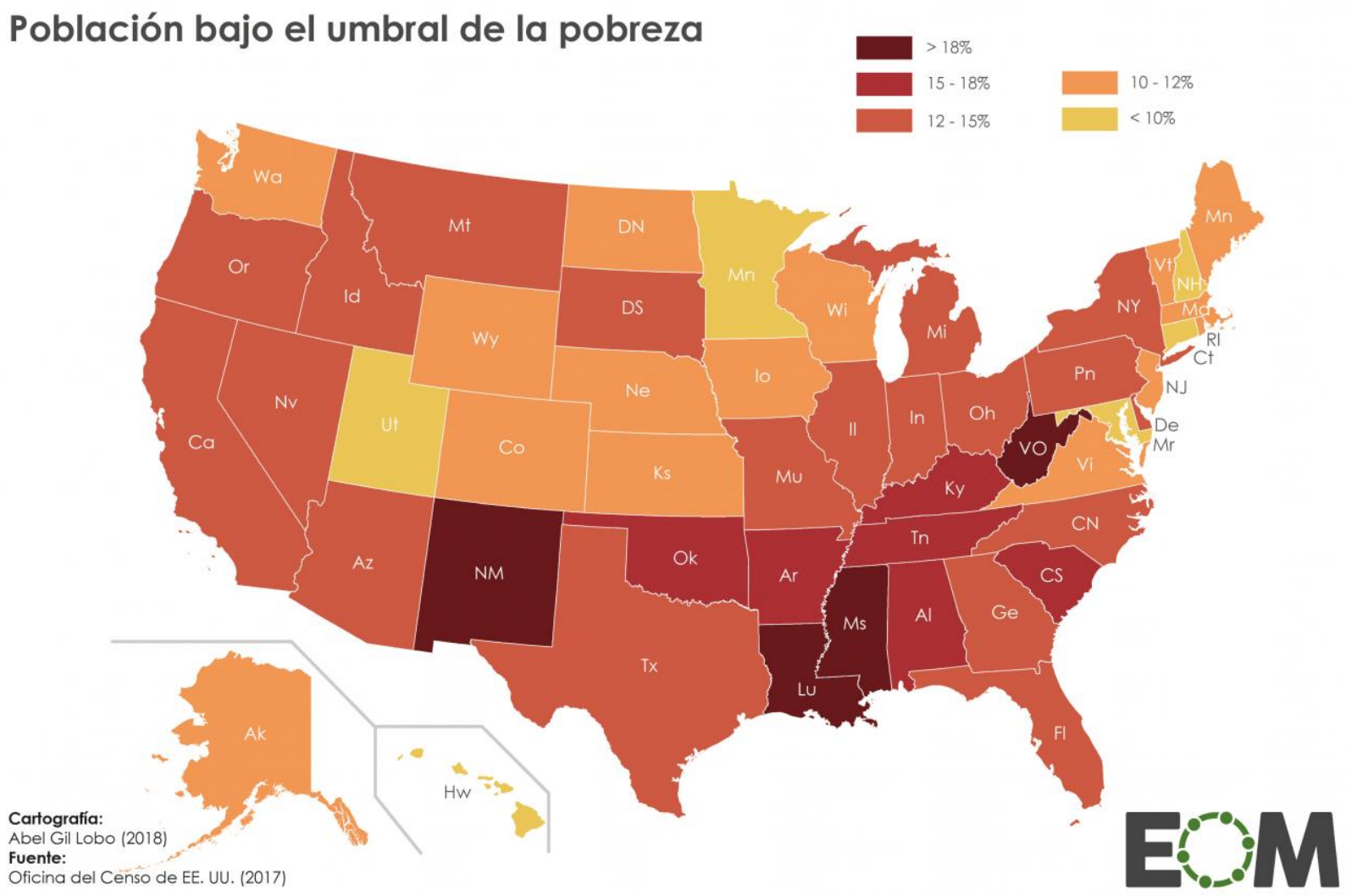

Figure 6. Poverty in the United States. El Orden Mundial (2018).

A brief study published on the website "The World Order (EOM)" in November 2018 indicated the following:

The United States is the third country with the greatest poverty gap in the OECD [Organization for Economic Cooperation and Development] after South Africa and Italy, the fourth with the highest proportion of the population living below the poverty line and the seventh with the highest income inequality. All of it from almost a quarantine of countries. (El Orden Mundial, 2018)

In context, it is important to note that despite the low level of unemployment in the United States, there is still a lack of more jobs and better remuneration because the economic growth in that country is not enough to lift a growing number of people out of poverty.

\section{Budgetary and Commercial Deficit}

Since 1975, that is to say for more than four decades, the trade deficit has become a real headache for the different governments, but the year 2019 is already a migraine for the Trump administration because the annualized figure reached 891 billion dollars (Sputniknews, 2019).

At current rates, the short-term deficit could reach one trillion dollars, which means that the United States imports much more than exports them. Of the countries with which this country has trade, five stand out, with the highest deficit. 
Table 5

Trade Deficit with Its Main Partners

\begin{tabular}{lll}
\hline Country & Trade & Deficit \\
\hline China & 636 billion & 375 billion \\
Canada & 582 billion & 18 billion \\
Mexico & 557 billion & 71 billion \\
Japan & 204 billion & 69 billion \\
Germany & 171 billion & 65 billion \\
\hline
\end{tabular}

Source: Amadeo (2019).

The above explains the trade war that the United States has initiated against China; however, it is not the Asian giant that directly blames this deficit, but other factors such as the global slowdown and the strengthening of the dollar that make products more expensive abroad. However, tariffs imposed on China have slowed the economy of that country, but US exports have also declined. In an interconnected world with multiple communicating vessels, you cannot take a step against the main trading partner without affecting your own economy.

The contrasts between the United States and China are very evident; the first imports the second export; the first has low savings rates while the second has high; the first has a strong currency while the second the downward adjustment; the first has a growth of the average GDP of $2 \%$ in the last six years while the second one grows at rates above $6 \%$; the first is consumerist while the second is the world's factory. In this context, the imposition of tariffs is a limited, partial, and incomplete way to balance the trade balance. Paul Krugman has indicated that "trade deficits have almost nothing to do with tariffs or other trade restrictions" (Sputniknews, 2019), so the trade war against China is lost in advance. Since the presidential campaign, Donald Trump promised to reduce the trade deficit, but by the end of 2018, US imports reached the highest point in a decade, registering an imbalance of more than 55 billion dollars per month. All of its main trading partners expanded their surplus balance as China, the European Union, and even Mexico. The truth is that the US economy produces less than it consumes and that makes it resort to imports that advance at breakneck speed.

In this scenario, a low unemployment rate could be counterproductive because it would push up wages; this would generate inflation and, ultimately, there would be increases in interest rates.

Table 6

Budget Deficit of the United States

\begin{tabular}{ll}
\hline Year & Deficit in billions \\
\hline 2016 & 585 \\
2017 & 665 \\
2018 & 800 \\
2019 & 900 \\
2020 & 1 trillion \\
\hline
\end{tabular}

Source: Yahoo Finanzas (2018).

Regarding the budget issue, the picture is not more encouraging because fiscal year 2018 closed with a deficit of 779 billion dollars, the highest since 2012 (Reuters, 2018) as a result of the tax cuts and the payment of interest on the debt that has been growing due to the increase in interest rates. In fiscal year 2018, the budget deficit represented $3.9 \%$ compared to $3.5 \%$ the previous year. Beyond the conjunctural aspect, the big problem 
is that the graphs show that in the last 44 years the United States has only registered a surplus in four years, from 1998 to 2001, which reveals that the deficit is a long-term structural problem.

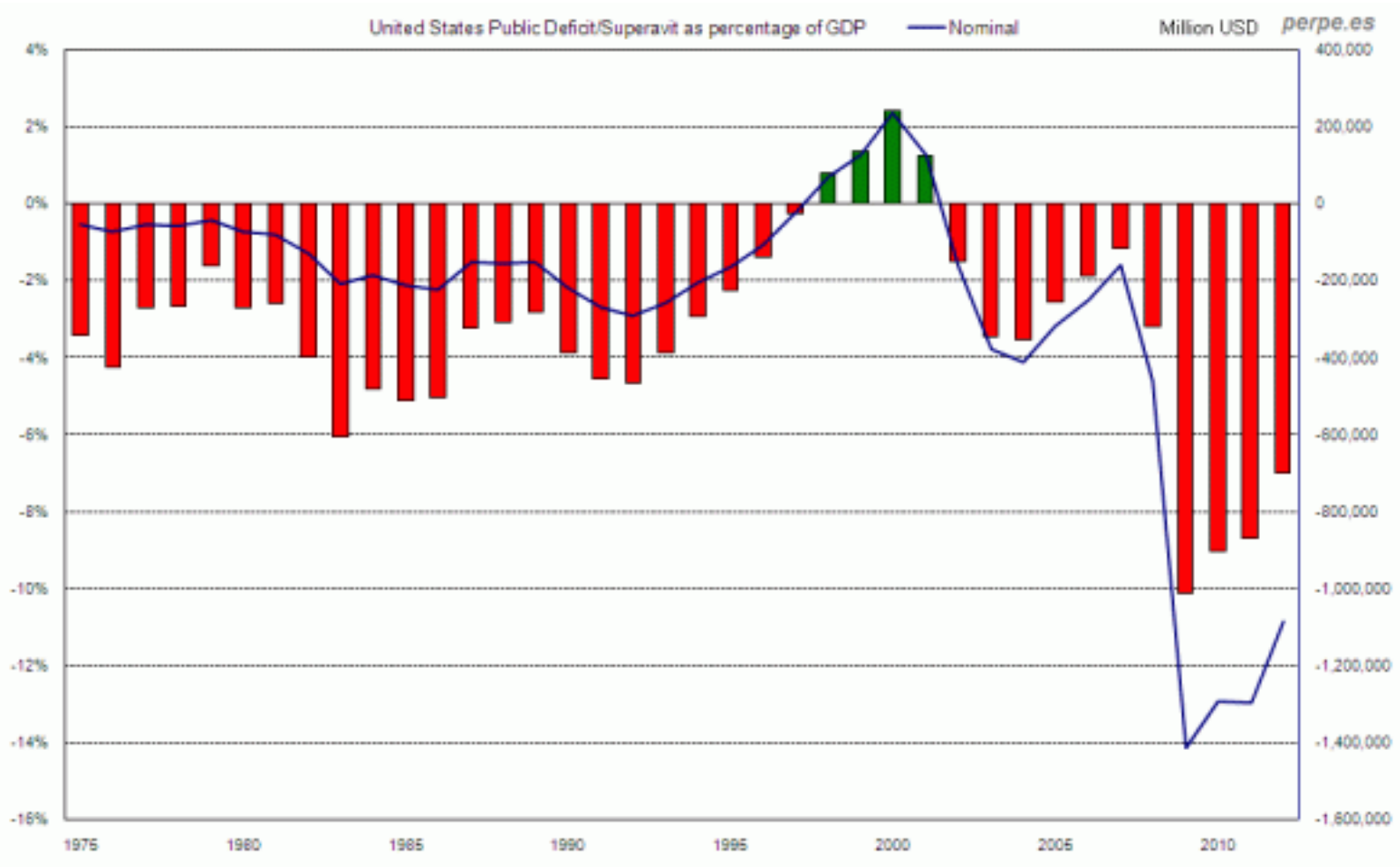

Figure 7. United States Public Deficit as Percentage of GDP since 1975. Perpe (2013).

In this regard there are two important points, the first of Bernard Baumohl, global economist in chief of Economic Outlook Group who mentioned "A healthy economy does not generate historical deficits" (Yahoo Finanzas, 2018). Another statement in the same vein was the Nobel Prize for economics Paul Krugman says "How the man of tariffs has become the man of deficits" and adds "Trump's twin deficits denote his dishonesty and ignorance" (Sputniknews, 2019).

A final reflection leads us to consider that all of the above has been caused by the neoliberal economic model established by the government of Ronald Reagan and resumed with new vigor by the Trump administration. The indicators that we have mentioned show the symptom of a great illness. Public indebtedness, the concentration of wealth, the increase in poverty, the budget and trade deficit are just some expressions of a greater problem. If the Trump government and the subsequent administrations do not reverse the trend, the US economy will reach a point of no return and inevitably fall into a chasm from which it can no longer exit

\section{Conclusion}

By the data indicated above, the indebtedness of the United States is colossal and unpayable and trying to reverse it or even stop it which will have enormous political and social economic costs that we do not believe that any government is willing to pay.

The country is addicted to credit and its budget cannot be financed without debt. The government, businesses, and citizens are on an unsustainable path in the long term. 
The dynamics of public debt has caused the citizens of that country to have one of the highest per capita debts in the world.

While exports are lower than imports, consumption is higher than savings and the government spends more than what the United States enters; it will continue in a vicious circle that in the long term will lead to financial bankruptcy with global repercussions.

For its part, the government must reduce its military budget mainly and understand that an arms race will take it to a scenario of unprecedented economic crisis. The model of permanent war economy is obsolete.

If the United States does not follow the logic that the first economic power in the world should be the creditor country and not the debtor, it will become a vulnerable nation in the face of its creditors and will weaken and lose influence among the various international actors.

The economy of inequality in which the United States lives has caused the gap between rich and poor to widen dangerously causing the emergence of leaders and social movements of the left, but also of the extreme right that confront and polarize large sectors of society that can generate social tensions with unprecedented repercussions.

The American Union has gone from a conjunctural crisis to a structural crisis and the different governments have not been able to recognize or stop this situation.

The neoliberal economic model adopted 40 years ago already gave everything it had to give; persisting in this modus operandi will only produce periods of ephemeral boom and increasingly deep and recurrent crises.

The United States is on an unsustainable trajectory that, if not corrected, will accentuate its phase of decline as a power.

\section{References}

ABC.es Internacional. (2011). Estados Unidos ha triplicado su deuda en los últimos 10 años. Retrieved from https://www.abc.es/20110801/internacional/abci-deuda-estados-unidos-201108011256.html

Agencies. (2019, June 26th). EU amaga con borrar partes de Irán. El Universal. Retrieved from https://www.eluniversal.com.mx/mundo/eu-amaga-con-borrar-partes-de-iran

Amadeo, K. (2019). US trade deficit by country, with current statistics and issues. Why America cannot just make everything it needs. Retrieved from http://www.thebalance.com/trade-deficit-by-country-3306264

Budget of the United States Government. (2016). Historical tables 2006. Retrieved from https://web.archive.org/web/20100410135032/http://www.whitehouse.gov/omb/budget/fy2006/pdf/hist.pdf

CNNMoney. (2017). Cuánto le ha costado a EU la guerra de 16 años en Afganistán? Retrieved from https://expansion.mx/mundo/2017/08/22/cuanto-le-ha-costado-a-eu-la-guerra-de-16-anos-en-afganistan

Conn, C. (2013). U.S. per capita government debt worse than Greece in Washington Examiner. Washington Examiner. Retrieved from https://www.washingtonexaminer.com/us-per-capita-government-debt-worse-than-greece

Die Presse. (2016). La deuda pública de EE.UU. alcanza los 19 billones de dólares y el 80\% durante la presidencia de Obama. Retrieved from https://www.oroyfinanzas.com/2016/02/deuda-publica-eeuu-alcanza-19-billones-dolares/

EC/AFP. (2019). Estados Unidos sube su gasto militar por primera vez en siete años. El Comercio. Retrieved from https://elcomercio.pe/mundo/eeuu/estados-unidos-sube-gasto-militar-estadounidense-primera-vez-siete-anos-noticia-630646

Egan, M. (2017). Record de desigualdad en Estados Unidos: El 1\% controla el 38.6\% de la riqueza del país. Retrieved from https://cnnespanol.cnn.com/2017/09/29/record-de-desigualdad-en-estados-unidos-el-1-controla-el-386-de-la-riqueza-del-pais/

El Orden Mundial. (2018). La pobreza en Estados Unidos. Retrieved from https://elordenmundial.com/mapas/la-pobreza-en-estados-unidos/

Expansión/Datosmacro.com. (2018). Deuda Pública de Estados Unidos. Expansión. Retrieved from https://datosmacro.expansion.com/deuda/usa

Federal Reserve Bulletin. (2017). Changes in U.S. family finances from 2013 to 2016: Evidence from the survey of consumer finances. Retrieved from https://www.federalreserve.gov/publications/files/scf17.pdf 
Ferrero, J. A. (2015). La China actual. Geoestrategia en su entorno Geopolítico (I Parte). Instituto Español de Estudios Estratégicos. Retrieved from http://www.ieee.es/Galerias/fichero/docs_marco/2015/DIEEEM09-2015_China_Actual_JAlbert.pdf

Freedman, S. (2012). America's per capita government debt worse than Greece. Retrieved from http://www.mygovcost.org/2012/02/23/americas-per-capita-government-debt-worse-than-greece/

Jiménez, A. (2013). La desigual distribución de la riqueza en Estados Unidos. El blog de Salmón. Retrieved from https://www.elblogsalmon.com/entorno/la-desigual-distribucion-de-la-riqueza-en-estados-unidos

Meschoulam, M. (2018). Risas en la ONU: Revisando el poder de EU. El Universal. Retrieved from https://www.informador.mx/ideas/Risas-en-la-ONU-revisando-el-poder-de-EU-20180929-0008.html

Montenegro, J. A. (2019). El desigual reparto de la riqueza amenaza para la democracia y el libre Mercado. Retrieved from https://cnnespanol.cnn.com/2019/04/19/el-desigual-reparto-de-la-riqueza-amenaza-para-la-democracia-y-el-libre-mercado/

Moreno, M. A. (2013). Parálisis fiscal de Estados Unidos muestra la precaria situación de la economía mundial. Retrieved from https://www.elblogsalmon.com/economia/paralisis-fiscal-de-estados-unidos-muestra-la-precaria-situacion-de-la-economia-m undial

OroyFinanzas.com. (2016). La deuda pública de EE.UU. alcanza los 19 billones de dólares y el 80\% durante la presidencia de Obama. Retrieved from https://www.oroyfinanzas.com/2016/02/deuda-publicade-eeuu-alcanza-19-billones-dolares/

Perpe. (2013). Déficit presupuestario en Estados Unidos desde 1975/Budget deficit in United States since 1975. Retrieved from http://www.perpe.es/2013/10/18/oc15013/

Piketty, T. (2014). Capital in the 21st century. Cambridge, Massachusetts. Retrieved from https://cronicon.net/paginas/Documentos/Piketty-El-capital-en-siglo-XXI.pdf

Reuters. (2018). Estados Unidos tiene su mayor déficit presupuestario desde 2012. Expansión. Retrieved from https://expansion.mx/economia/2018/10/15/estados-unidos-tiene-su-mayor-deficit-presupuestario-desde-2012

Shambaugh, J. (2017). Estados Unidos: Quiénes son los 40 millones de pobres que viven en el país más rico del mundo? Brookings Institution. BBC News Mundo. Retrieved from https://www.bbc.com/mundo/noticias-internacional-42315879

Sputnik Mundo. (2013). La Guerra de las Galaxias aceleró el colapso de la URSS. Retrieved from https://mundo.sputniknews.com/opinion/20130327156719923/

Sputniknews. (2018). La deuda pública de EEUU ha alcanzado un nuevo récord, superando los 21 billones de dólares. Esto ha quedado plasmado en los datos del Departamento del Tesoro de EEUU. Retrieved from https://mundo.sputniknews.com/economia/201803191077150311-deuda-publica-eeuu-21-billones/

Sputniknews. (2019). El colosal déficit comercial de Trump. Retrieved from http://mundosputniknews.com/firmas/201903151086092360-guerra-comercial-de-eeuu/

Stiglitz, L., \& Bilmes, J. (2008). La Guerra de los tres billones de dólares. México: Taurus.

Wikimedia.commons.org. (2017). Gini Index World Map, income inequality distribution by country. World Bank.svg. Retrieved from https://commons.wikimedia.org/wiki/File:2014_Gini_Index_World_Map,_income_inequality_distribution_by_country_per_Wo rld_Bank.svg

Yahoo Finanzas. (2018). Por qué Trump se equivoca diciendo que es la "economía más fuerte" de la historia. Retrieved from https://es.finance.yahoo.com/noticias/por-que-trump-se-equivoca-diciendo-que-es-la-economia-mas-fuerte-de-la-historia-160 340894.html 